\title{
GENERALIZATIONS OF SOME INEQUALITIES OF OSTROWSKI-GRÜSS TYPE
}

\author{
C. E. M. Pearce, J. PeČarić, N. Ujević And S. Varošanec
}

Abstract. We provide generalizations and improvements of a variety of recent results for the Ostrowski and Simpson inequalities.

Mathematics subject classification (1991): 26D10.

Key words and phrases: Ostrowski-Grüss inequality, Simpson's rule.

\section{REFERENCES}

[1] S. S. Dragomir AND S. WANG, An inequality of Ostrowski-Grüss type and its applications to the estimation of error bounds for some special means and for some numerical quadrature rules, Computer Math. Appl. 33 (1997), 15-20.

[2] I. FEDOTOV AND S. S. DRAGOMIR An inequality of Ostrowski's type and its applications for Simpson's rule in numerical integration and for special means, Math. Inequal. Appl. 2 (1999) 491-499.

[3] M. MATIĆ, J. PEČARIĆ AND N. UJEVIĆ, Improvement and further generalization of some inequalities of Ostrowski-Grüss type, to appear in Computer Math. Appl.

[4] D. S. Mitrinović, J. E. PEČARIĆ AND A. M. FInK, Inequalities involving functions and their integrals and derivatives, Kluwer Acad. Publ., Dordrecht/Boston/Lancaster/Tokyo, 1991.

[5] C. E. M. PEARCE AND J. PEČARIĆ, On Anastassiou's generalizations of the Ostrowski inequality and related results, to appear in J. Comput. Anal. and Applic. 